\title{
The Effect of Motivation and Islamic Leadership on Employee Work Performance with Discipline as an Intervening Variable (Case study on Baitut Tamwil Muhammadiyah (BTM) in Central Java)
}

\author{
Wiwit Setyowati ${ }^{1}$, Suryo Budi Santoso ${ }^{2}$, Herni Justiana Astuti ${ }^{3}$ \\ \{1qkyowin@gmail.com, ${ }^{2}$ suryobs@gmail.com, ${ }^{3}$ herni99@gmail.com\} \\ ${ }^{1}$ Master of Management, Universitas Muhammadiyah Purwokerto \\ ${ }^{2}$ Department of Accounting, Universitas Muhammadiyah Purwokerto \\ ${ }^{3}$ Department of Management, Universitas Muhammadiyah Purwokerto
}

\begin{abstract}
This study aims is to find the empirical evidence and analyze the effect of motivation and Islamic leadership on employee work performance of BTM in Cental Java with discipline as an intervening variable. The population of this study is a total of 161 employees of BTM in Central Java, with the total amount of sample is 100 respondences. The respondent were chosen using purposive sampling technique and the study was conducted for 2 months from March to may 2020. Data analysis techniques using the Partial Least Square-Statistical Equation Method (PLS-SEM) with SmartPLS-3 software tools. The result of this study shows that motivation and Islamic leadership have a positive but not significant effect on employee performance, the discipline has a positive and significant effect on employee performance. Motivation and Islamic leadership have a positive and significant effect on discipline. Motivation influences employee performance through discipline, but Islamic leadership can not influence employee performance through discipline.
\end{abstract}

Keywords: Motivation, Islamic Leaderhip, Employee Work Performance, Discipline.

\section{Introduction}

Human resource is the only resource who have sense, desire, skills, knowledge, encouragement, and creativity. Technological advancement, availability of capital and sufficient material in a company still cannot eliminate the role of human resources to achieve its purpose [1]. Therefore, maximizing the potency of human resources is a way to improve performance to achieve organizational goals. Performance is work result both in quality and quantity achieved by human resources per unit period time in carrying out his work duties under the responsibility given to him [2]. BTM as an Islamic microfinance institution that supports Micro Small and Medium Enterprises (MSMEs) is demanded to have good performance. Company performance is strongly influenced by human resources performance.

Many factors affect the performance of human resources [3]: 1) Employee internal factors: factors within the employee that are inherited from birth and factors that are obtained when he develops. Inherited factors, such as talent, personal nature, as well as physical and mental condition. Factors obtained, such as knowledge, skills, work ethics, work experience, and 
work motivation. 2) Organizational internal environmental factors: support from the organization where it works. The internal environmental factors of the organization include the vision, mission, and goals of the organization, organizational policies, technology, organizational strategy, management systems, compensation, leadership, organizational culture, and co-workers. 3) Organizational external environmental factors are the circumstances, events, or situations that occur in the organization's external environment that affect employee performance. The external environmental factors of the organization include economic life, political life, social life, culture and religion of the community, and competitors.

Motivation is one of the factors that influence the level of employee performance. Mental factors and motivation of human resources affect the achievement of company targets. Several studies mention that motivation has a positive and significant effect on employee performance $[4,5]$. The different result states that motivation has a positive but not significant effect on employee performance [6].

Leadership is a very important issue in Islam because leadership is related to the benefit of people such as justice, welfare, safety, and, comfort. In the Islamic view, every human being is a leader and each leader will be held accountable. As explained in a Hadith which means: "Everyone in between you is the leaders and will be held responsible for their leadership." (Narrated by Bukhari and Muslim). Islamic leadership is a process or ability of others to direct and motivate the behaviour of others, and there are cooperative efforts by following the Qur'an and the Hadith to achieve the desired goals together [7]. The role of the leader is very important to achieve organizational goals. Leaders who are consistent with honest behaviour, trustworthy, smart and open will affect employee performance. Several studies mention that leadership has a positive and significant effect on employee performance [8]. Different from the research which argues that leadership has a positive but not significant effect [9].

One of the employee internal factors which influence work performance is discipline. Discipline is the key to the success of the programs that will be implemented and services to consumers can be provided professionally and optimally. Discipline is also very important for increasing the efficiency and effectiveness of improving the performance of all employees. Work discipline is one's awareness and willingness to obey all company regulations and social norms [10]. The importance of discipline in supporting performance can be seen from some research conducted by $[11,12]$ who state that employee discipline has a positive and significant effect on performance. On the contrary other research states that discipline has no significant effect on performance [13].

All organizations are required to improve and maintain good performance. Company performance depends on individual work. The object of the research is BTM in Central Java. BTM is short of Baitut Tamwil Muhammadiyah, the microfinance institution that operates based on sharia principles. Principle Sharia means all financial transactions are carried out by following the agreement of Islamic law. The employee as the human resources of BTM is moslem, so it has a good potency to apply the Islamic value in the organizational daily activities. The location chosen was Central Java province, as it has the highest number of BTM in Indonesia.

A preliminary survey on the sample of BTM in Central Java found that employee discipline was still low, especially in terms of punctuality. Employee ratings of leaders are also low on indicators of honesty and open management. The result shows that employee performance of the BTM influenced by Islamic Leadership and discipline, while motivation has no significant effect on employee performance. Motivation of the employee influence the discipline, meanwhile the Islamic leadership does not affect the discipline. 
This study develops a model invented by [9] with the variable Islamic leadership, Islamic work Ethics on employee work performance in RSI Siti Hajar Mataram. Further development research was carried out by [8] with the variable motivation, Islamic leadership and work satisfaction on employee performance. Some of these researches emphasize the effect of motivation and Islamic leadership on employee performance. This study developed the model by adding the discipline as an intervening variable from previous research to predict its effect on employee performance of BTM in Central Java

\subsection{Research Purposes}

Based on the theory, previous research and, the above phenomenon, the writer interested in researching the effects of motivation and Islamic leadership on employee performance with discipline as an intervening variable, case study on BTM in Central Java. Therefore, the purpose of the study focuses on finding empirical evidence and analyse the effect of those variables and seeks the answer to the following research questions:

RQ1. Do motivation has a positive and significant effect on employee performance?

RQ2. Do Islamic leadership has a positive and significant effect on employee performance?

RQ3. Does discipline has a positive and significant effect on employee performance?

RQ4. Do motivation has a positive and significant effect on discipline?

RQ5. Do Islamic leadership has a positive and significant effect on discipline?

RQ6. Will motivation affect work performance with discipline as an intervening variable?

RQ7. Will Islamic leadership affect work performance with discipline as an intervening variable?

\section{Literature Review}

\subsection{The Hierarchy of Needs Abraham Maslow}

Abraham maslow propounded one widely quoted observation on what motivates people. He said that people have a hierarchy of five types of needs: Physiological (food, water, warmth), security (a secure income and job), social (friendship and camaradarie), self-esteem (respect), and self-actualization (becoming the person you believe you can become). According to Maslow's prepotency process principle, people are motivated first to satisfy each lower-order need and then, in sequence, each of higher-level needs [14].

\subsection{Motivators by Frederick Herzberg}

Frederick Herzberg said the best way to motivate someone is to organize the job so that doing it provides the feed-back and challenge that helps satisfy the person's higher level needs for things like accomplishment and recognition because the needs are relatively instable. The hygienes factors (factors outside the job, such as working condition, salary, incentive pay) that satisfy lower-level needs are different from those motivators that partially satisfy higher-level needs. Adding more hygiene to the job is an inferior way to try to motivate someone.

Instead of reliying hygiene, managers interested in creating a self-motivated workforce should emphasize job contents or motivator factors. Managers enriching worker's job to make the jobs are more challenging and by providing feedback and recognition (intrinsically motivating). When one is instinsically motivated, just doing the job provides the motivation. This theory makes the point that relying exclusively on financial incentives is risky. The 
employer should also provide the recognition and challenging work that most people desire [14].

\subsection{Performance}

Performance is the work achieved by an individual according to his role or task within a certain period, which is associated with a certain size and value or standard of the organization where the individual works [15]. Performance is all results produced in specific job functions or activities during specific periods [16].

Factors that affect performance [17] are: 1) Personal/individual factors, including knowledge, skills, self-confidence, competence, discipline, motivation, and commitment possessed by each individual. 2) Leadership factors, including quality in providing encouragement, enthusiasm, direction, and support provided by managers and team leaders. 3) Team factors, including quality of support and enthusiasm provided by colleagues in a team, trust in fellow team members, cohesiveness and, the tightness of the team's budget. 4) System factors, including work systems, work facilities, or infrastructure provided by the organization, organizational processes.5) Contextual (situational) factors, including pressures and changes in the external and internal environment and performance culture in the organization.

The indicators to measure employee performance are [18]: 1. Quality: Quality of work includes timelines, accuracy, ability, and skills of employees, 2. Quantity: work standards of quantity to be produced/settled, 3. Timeliness: the time required to complete a job/get it done quickly 4. Cost-effectiveness: related to the level of use of the organizational resources (people, money, materials, technology) in getting results or reducing the use of unnecessary materials, 5. Need for Supervision: the ability of individuals to complete work without the supervision of the leader, 6. Interpersonal Impact: the ability of individuals to increase the feeling of self-esteem, goodwill, and cooperation among co-workers and subordinates.

\subsection{Discipline}

Work discipline is the awareness and willingness of a person to obey all company regulations and social norms [10]. Work discipline is a tool used by managers to communicate with employees so that they are willing to change behavior and as an effort to increase awareness and willingness to follow all company regulations [14]. Work discipline is a person's behavior that complies with regulations, existing work procedures or discipline is an attitude, behavior, and actions that are under the regulations of both written and unwritten organizations [1]. Factors that influence the work discipline mentioned as follows [10]: 1). The amount of compensation 2). The exemplary of leadership. 3). Definitive rules to guide. 4). The courage of a leader in taking action. 5). Leader's supervision 6). The attention to employees 7). Create a habit that supports discipline.

The indicators of discipline [1] are 1. Obedient to the rules of time, 2. Obedient to the company regulations, 3. Obedient to the rules of behavior at work, 4. Obedient to other regulations

\subsection{Motivation}

Motivation is a process carried out to move someone so that their behavior can be directed at real efforts to achieve predetermined goals[19] 2) Motivation is the process of influencing or encouraging from outside a person or work group so that they want to carry out something that has been determined [20]. Motivation comes from the word motives or things or circumstances that cause impulse [2]. There are some factors that influence motivation [21]: a) 
Promotion; b) Job Performance; c) The work itself; d) Awards; e) Responsibility; f) Recognition; g) Success in Work.

The indicators of motivation [22] are: Physiological: the most fundamental need as food, home living, fashion, sexual, Security: the need for security on work, health, retirement, educational fee, Social: the need to love and be loved, a sense of belonging, well-received, friendship, Self-esteem: the need to be recognized by others, have a good reputation and confidence and respected by everyone and get attention, Self-actualization is a person's needs, encouragement or desire to fulfill his ambitions, which includes growth, achieving potential, and fulfilling his personal needs

\subsection{Islamic Leadership}

Islamic leadership is a process or ability of others to direct and motivate the behavior of others and there is a collaborative effort by following the Qur'an and Hadith to achieve the desired goals together [7]. Leadership in the Islamic perspective is described as trust or mandate which involves a psychological contract between the leader and the follower to do good deeds. Thus a leader must have a strong moral character [23]. Thus, a strong moral charácter must be owned by the leader.

From the character of Prophet Muhammad SAW, there were four dimensions of his leadership as follows [7]: A. Siddiq / Honesty: Those who have the characters of honesty are always in line between their speaking and their deeds, according to Islamic law. Including the the honesty are: (a) The attitude, (b) in doing something/working, and (c) for financial purposes. B. Amanah / Trust: sense of responsable and trustworthy. C. Fathonah / Smart: Able to solve any problems, having a good work concept, and broaden knowledge. D. Tabligh: Not only the ability to inform but also give the action about what he has just been informed in this daily life activities and the ability of good negotiation.

\subsection{Hypothesis Development}

\section{The effect of motivation on employee performance}

Performance of an employee influenced by some factors [17]: 1) Personal/individual factors (knowledge, skills, the ability of confidence, competence, discipline, motivation, and commitment possessed by each individual. 2) Leadership factors, 3) Team factors (quality of support and enthusiasm of colleagues in a team, the trust between co-workers, cohesiveness and, the tightness of the team's budget. 4) System factors (work systems, facilities or infrastructure provided by the organization, organizational processes, 5) Contextual/situational factors (pressures and changes in the external and internal environment and performance culture in the organization).

This concept was supported by research conducted[4,5] by Sidanti (2015), Wijayanti, and Miftahudin (2016) which state that motivation has a positive and significant effect on employee performance. Inline[24] (akbar 2018) stated that sustainable motivation in the form of direction and reward to employees can provide the stimulation to the employees to work better in order to achieve organizational goals. In the other words, highly motivated employees can complete their work better which means better employee performance. The findings of these studies strongly suspected that the employee work motivation will significantly effect on employee performance. Based on the study above, a hypothesis can be formulated: H1: Employee motivation has a positive and significant effect on employee performance 


\section{The effect of Islamic leadership on employee performance}

Previous research states that performance is influenced by leadership management [25]. Islamic leadership is a process or ability of others to direct and motivate the behaviour of others, and thee ae collaborative efforts in accordance with the Alqur'an and Hadith to achieve the desired goals ogether[7]. This theory supported by research [26,8]), which stated that Islamic leadership has a positive and significant effect on the quality of employee performance. A leader in a work environment who has Islamic characteristics can influence his employees to give their best performance. Based on the theory and the studies above, a hypothesis can be formulated:

H2: Islamic leadership has a positive and significant effect on employee performance

\section{The effect of Discipline on employee performance}

One of the factors which influence employee performance is discipline.Work discipline is a mental attitude that is reflected in the actions or behavior of individuals, groups, communities in the form of obedience or obedience to established regulations [27]. Research conducted by[11,12] states that discipline has a positive and significant effect on employee performance. This is supported by next research[28] which states that discipline has a significant effect on the application of TQM and employee performance. Discipline is an important factor for an employee to achieve a good performance. The more disciplined a person is, the better his performance is because the targets that have been set can be achieved on time. Based on the study above, a hypothesis can be formulated:

H3: Work discipline has a positive and significant effect on employee performance.

\section{The effect of motivation on discipline}

The high motivation of an employee encourages them to be disciplined at work. Motivation can be intrinsic or extrinsic (eg salary/wages, position/power, praise, etc. Previous research[29] found that extrinsic motivation has a significant effect on discipline. The influence of this variable shown by the path coefficient of 1.403 or the influence of extrinsic motivation on discipline is $14.03 \%$. The result of the study in line with the next research[30] which state that motivation has a positive and significant effect on the discipline. High motivation will encourage employees to be disciplined at work. Based on the study above, a hypothesis can be formulated:

H4: Employee motivation has a positive and significant effect on wor

\section{The effect of Islamic Leadership on discipline}

Leadership in an Islamic perspective described as a belief or mandate that involves a psychological contract between the leader and followers to do good deeds. Thus a leader must have a strong moral character [23]. The attitude and example of a leader influence employee discipline at work. Leadership, supervision, educational punishment, and leadership assertiveness influence employees to obey all the company rules. A research [31] found that leadership has a positive and significant effect on work discipline. Likewise [32] states that leadership has a positive and significant effect on employee work discipline. based on the description above, a hypothesis can be formulated:

H5: Islamic leadership has a positive and significant effect on work discipline.

The effect of motivation on employee performance with discipline as an intervening variable

A research [33] found that motivation and leadership style has a positive effect on work discipline and have an impact on employee performance. This result supported by [30] which states that motivation affects performance through work discipline. An employee with good motivation will get a good performance based on high discipline. From the description above, a hypothesis can be formulated: 
H6: Motivation has an effect on employee performance with work discipline as an intervening variable.

The effect of Islamic leadership on employee performance with discipline as an intervening variable

Previous research [34] states that leadership can directly affect employee performance and indirectly leadership can affect employee performance mediated by work discipline. Islamic leadership that is honest, trustworthy, intelligent and participatory will encourage someone to work in a disciplined manner. Disciplined employees will achieve better work results. From the description above, a hypothesis can be formulated:

H7: Islamic leadership affects employee performance with discipline as an intervening variable.

The conceptual framework supported by previous studies that contained the relationship between variables is shown in fihure 2.1:

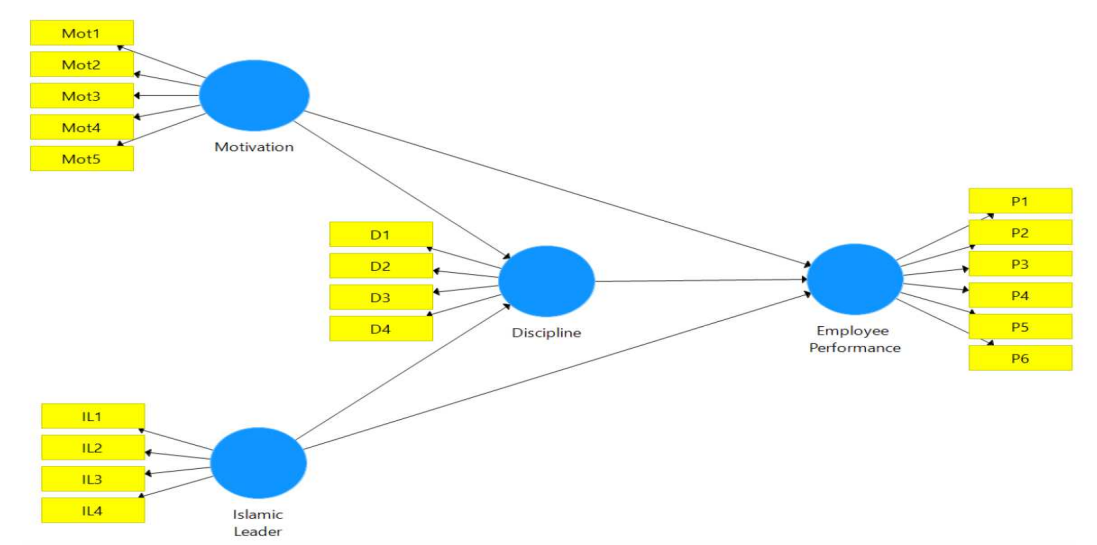

Fig.1. Conceptual Framework

The conceptual model in this study stated that the relationship between variables is built based on a literature review and supported by previous research. The conceptual framework used in this study is expected to provide an overview of research conducted by the researcher's plans.

Motivation (X1) and Islamic leadership (X2) influence the discipline (Z) of an employee. Meanwhile, the discipline $(Z)$ will mediate the effect of motivation (X1) and Islamic leadership (X2) on employee performance(Y).

\section{Method}

The methodology of the research is quantitative, with the population is all the 161 employees of BTM in Central Java. The sample of this research is 100 respondents. The number of PLS samples can be calculated by ten times the number of endogenous variables (independent variables) in the model [36]. This study uses 3 endogenous variables so that the minimum sample size is $3 \times 40=30$ people.

The respondent was chosen using a purposive sampling technique, respondents should have at least one year of service in the company. The hypothesis was examined by Partial 
Least Square - Statistical Equation Method (PLS-SEM) to obtain causality relation result of each variable which was developed in the model. About 130 questionnaires distributed and collect. A letter of introduction been given to the leader of BTM or manager in charge to inform him/her with the objectives of the research and to get the support of participation regarding the questionnaires. The questionnaire was sent in stages depends on the approval obtained, and collected afterward. Instruments measured using 5 points Likert scale which indicates strongly agree, agree, neither agree nor disagree, disagree and strongly disagree.

\section{Result And Discussion}

\subsection{Respondent characteristic and descriptive variables}

Data measurement to 100 respondents shows that $52 \%$ of respondents are female and $48 \%$ are male. The age of respondents are $62 \%$ by $21-30$ years, $21 \%$ by $31-40,11 \%$ by $41-50,4 \%$ by $<20$ and $1 \%$ by above 50 . The Educational background of the respondents is a high school $(48 \%)$, undergraduate $(37 \%)$, and diploma $(15 \%)$. Based on years of service there are $59 \%$ by $0-5,(21 \%)$ by $6-10,11 \%$ by $>15$ and $9 \%$ by $11-15$

\subsection{Outer Loading}

It can be seen that table 5.1 describes a measurement model of Outer Loading. All indicators are acceptable, except Physiological Needs (Mot1) and Interpersonal Impact (P5), because loading factors are less than 0.5. On run 2, the Mot1 and P5 indicators were removed because the outer loading is less than 0.5. Likewise, the result with AVEs, all variables meet the criteria for Convergent Validity which is greater than 0.5 . So, all indicators and variables are valid.

\subsection{Inner Model}

The goodness of fit examined by looking at the coefficient determination (R-Square). It is used to measure how much the endogenous variables influenced by other variables. R2 of 0.67 and above for endogenous latent variables in the structural model indicate the influence of exogenous (influencing) variable on endogenous (influenced) variables included in either category. Whereas if the result is $0.33-0.67$ it is included in the moderate category, and if the result is $0.19-0.33$ then it is included in the weak category [36]. These values explain that motivation, Islamic leadership, and discipline influence employee performance by $36.5 \%$, while $63.5 \%$ is influenced by other variables that are not examined. And motivation and Islamic leadership influence discipline by $31.7 \%$ while $68.3 \%$ is influenced by other variables that are not examined. From the result, R2 for employee performance is in a moderate category (0.33-0.67), and R2 for discipline is on a weak category (0.19-0.33).

The Path coefficient test is used to show the strength of the effect of independent variables on the dependent variable. Figure 5.1 shows that discipline has the highest influence on employee performance with a score of $34.2 \%$, and Islamic leadership has the lowest influence of $11.4 \%$. Islamic leadership affect discipline by $33.4 \%$, more than motivation by $33.1 \%$ 
Table 1. Outer Loading 1

\begin{tabular}{llccc}
\hline Variables & \multicolumn{1}{c}{ Indicators } & $\begin{array}{c}\text { Loading } \\
\text { Factor } \\
\text { Run } 1^{*}\end{array}$ & $\begin{array}{c}\text { Loading } \\
\text { Factor } \\
\text { Run 2 }\end{array}$ & Result \\
& & 0.199 & Rejected & Rejected \\
\hline Motivation[23] & Physiological & 0.758 & 0.738 & Accepted \\
& Security & 0.717 & 0.707 & Accepted \\
& Social & 0.702 & 0.716 & Accepted \\
& Self-esteem & 0.686 & 0.709 & Accepted \\
& Self-actualization & 0.756 & 0.756 & Accepted \\
Islamic & Shiddiq (honesty) & 0.872 & 0.875 & Accepted \\
Leadership[29] & Amanah(trustworthy) & 0.855 & 0.856 & Accepted \\
& Fathonah (smart) & 0.746 & 0.742 & Accepted \\
& Tabligh (informative) & 0.656 & 0.665 & Accepted \\
Discipline[1] & Obedient of time & 0.834 & 0.832 & Accepted \\
& Obedient of regulations & 0.863 & 0.860 & Accepted \\
& Obedient of work behavior & 0.877 & 0.874 & Accepted \\
& Obedient of other regulations & 0.830 & 0.816 & Accepted \\
Employee & Quality & 0.732 & 0.738 & Accepted \\
Performance[22] & Quantity & 0.770 & 0.800 & Accepted \\
& Timelines & 0.660 & 0.677 & Accepted \\
& Cost effectiveness & 0.636 & 0.649 & Accepted \\
& Need for supervision & 0.287 & Rejected & Rejected \\
\hline
\end{tabular}

${ }^{*}$ Accepted if loading factor more than 0.5

Figure 2 shows Structural Equation Modelling of Employee Performance by Motivation, Islamic Leadership and Discipline

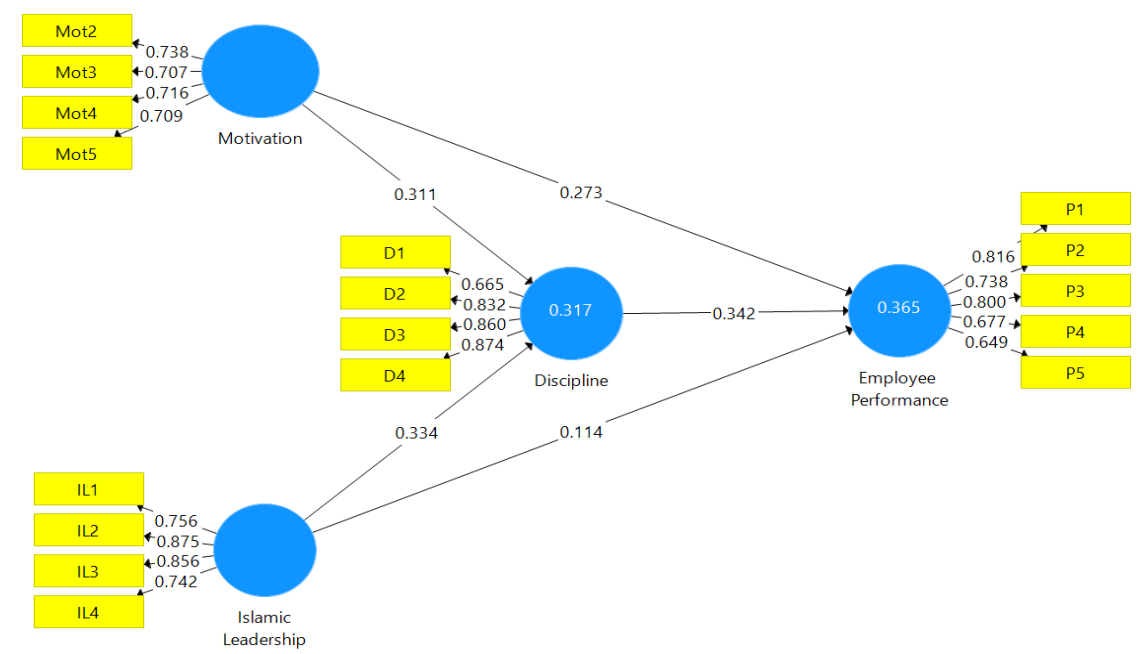

Fig.2. Structural Equation Modelling of Employee Performance 
Table 2. Relationships, Path Coefficients, P Values, Results

\begin{tabular}{llll}
\hline Relationships & Path & P & Results \\
& Coefficients & values & \\
\hline Motivation $\rightarrow$ employee performance (H1) & 0.273 & 0.053 & Rejected \\
Islamic leadership $\rightarrow$ employee performance (H2) & 0.114 & 0.338 & Rejected \\
Discipline $\rightarrow$ employee performance (H3) & 0.342 & 0.001 & Accepted \\
Motivation $\rightarrow$ discipline (H4) & 0.311 & 0.001 & Accepted \\
Islamic leadership $\rightarrow$ discipline (H5) & 0.334 & 0.022 & Accepted \\
Motivation $\rightarrow$ discipline $\rightarrow$ employee performance (H6) & 0.106 & 0.033 & Accepted \\
Islamic leadership $\rightarrow$ discipline $\rightarrow$ employee performance & 0.114 & 0.122 & Rejected \\
(H7) & & & \\
\hline
\end{tabular}

Table 2 describes the results of the relationship. It can be seen that hypotheses accepted except $\mathrm{H} 1, \mathrm{H} 2$, and $\mathrm{H} 7$.

\subsection{Discussion}

\subsubsection{Motivation on employee performance}

The hypothesis is accepted if the value of T-Statistics is > T-Table (1.96) or the P-Value $<0.05$ [36]. The print out of calculation using smartPLS3 on the table shows the influence of motivation has a T-statistic of $1.940(<1.96)$ and P-Value of $0.053>0.05$. The result indicates that motivation has a positive but not significant effect on employee performance. H1 which stated that motivation has a positive and significant effect on employee performance is rejected.

The result of the study is not in line with previous research [4,5] which stated that motivation has a significant effect on employee performance. But the notion of this research is consistent with the view [6] in which they describe that motivation has no significant effect on employee performance.

Employee motivation does not affect employee performance because the working period of the most employee is still on 0-5 year, and the age of the respondents are still under 30 years old. It means their motivation for work is not strong yet or in the experimental period. The data showed in table 5.1 also found that mot1 (physiological motivation) has the lowest score of the motivation variable (0.199). That means that employee's motivation no longer about matter or money, but more to safety, social and appreciation, or self-actualization.

\subsubsection{Islamic leadership on employee performance}

The results of the analysis indicate that the effect of Islamic leadership on employee performance of BTM in Central Java is positive but not significant. The t-statistic is 0.960 less than 1.96 and the p-value is 0.338 higher than 0.05 . Thus, H2 which stated that Islamic leadership has a positive and significant effect on employee performance is rejected.

The result is contrary to the study in which mentioned that leadership has a significant effect on employee performance [8,26]. The finding of the research in line with the research which stated that Islamic leadership not affected employee performance [9].

The role of Islamic leadership does not significantly affect employee performance because employees can always carry out their duties and responsibility to get optimum performance even without supervision from the leaders. Employees feel confident and sure that they can control themselves. According to the locus of control theory [36] employee has confidence 
that their behavior influences their fate. They will succeed if they work hard but will fail because of a lack of competence and motivation.

\subsubsection{Discipline on employee performance}

Table 5.2 shows that the influence of discipline on employee performance has t-statistic $3.412(>1.96)$ and $p$-value $0.001(<0.05)$. The result indicates that discipline has a positive and significant effect on employee performance. Thus, H3 accepted. The higher the work discipline of an employee, the better the performance.

The empirical evidence in line with the statement that the responsibility of improving working discipline will improve the quality of employee performance $[11,12]$. In contrast, the research before [13] stated that discipline has no significant effect on employee performance

\subsubsection{Motivation on discipline}

The result shown in the table above indicated that motivation has a significant effect on discipline. The analysis result mentions that the t-statistics is 3.220 higher than 1.96 and the pvalue is 0.01 less than 0.05 . Based on this empirical evidence, $\mathrm{H} 4$ stated that motivation has a positive and significant effect on the discipline of the BTM employee accepted.

The higher the motivation of an employee, the more work discipline will increase. An employee with good motivation on work will increase their discipline. This evidence in line with the research in which stated that motivation has a significant effect on discipline [29]. This result consistent with the theory which mentioned that discipline also influenced by human relations [10]. Human relation is a social need in the theory of motivation [14]. The motivation given by someone on their social relation will influence someone to discipline.

\subsubsection{Islamic Leadership on Discipline}

Based on the finding, Islamic leadership significantly influence on employee performance. The t-statistic is 2.296 higher than 1.96 and the p-value is $0.022(<0.05)$. Thus, it is proven that Islamic leadership has a positive significant effect on discipline. Inline [31] stated that Islamic leadership has a significant effect on discipline. H5 accepted.

The result is consistent with the theory[10] in which mentioned that discipline influenced by some factors: 1 . Intention and ability, 2. Leadership, 3. Incentive, 4. Justice, 5. Supervision, 6. Punishment, 7. The firmness of a leader, and 8. Human relation.

\subsubsection{Motivation on employee performance through discipline}

The result shown in the table above indicated that motivation has a significant effect on employee performance through discipline. The analysis result mentioned that the T-Statistics is 2.336 higher than 1.96 and P-Value is 0.032 less than 0.05 . Based on this empirical prove, motivation has a positive and significant effect on employee performance through discipline. Thus H6 accepted.

The finding of this research in line with the previous research [30] which stated that motivation has a positive and significant effect on employee performance through discipline. This result consistent with the theory [3] which mentioned that employee performance influenced by some factors, one of them is an internal factor as competence, self- confidence, motivation, discipline, and individual commitment. 


\subsubsection{Islamic leadership on employee performance through discipline}

The result shown in the table above indicated that Islamic Leadership has a positive effect on employee performance through discipline, but not significant. The analysis result mention that the T-Statistics is 1.549 less than 1.96 and P-Value is 0.122 higher than 0.05 . Based on this empirical prove, $\mathrm{H} 7$ which stated that Islamic leadership influence employee performance through discipline is rejected. The result of this study not in line with previous research [34] which states that leadership can directly affect employee performance and indirectly leadership can affect employee performance mediated by work discipline.

\section{Conclusion}

Based on the analysis and discussion, the conclusion is that not all of the hypotheses are accepted. Motivation and Islamic leadership have a positive but not significant effect on employee performance. Discipline has a positive and significant effect on employee performance. Motivation and Islamic leadership have a positive and significant effect on discipline. Motivation influences employee performance through discipline, but Islamic leadership can not influence employee performance through discipline. Physiological motivation is no longer as a basic indicator in building the motivation of the employee. Employee motivation has changed into the safety, social, and appreciation. The interpersonal effect has the lowest score in supporting employee performance. It means the leader has to support the employee to develop themselves and try to improve the effectiveness of how to work both independently and teamwork to obtain optimal results.

The value of R2 for employee performance is in the moderate category. It means motivation, Islamic leadership, and discipline not really influence employee performance. In further research, it is suggested to study about other variables that influence employee performance such as competence, incentives, work satisfaction, organizational behavior, work culture, etc.

\section{References}

[1] Sutrisno, Edi: Manajemen Sumber Daya Manusia Edisi pertama. (Kencana Prenada Media Group, Jakarta, 2009)

[2] Mangkunegara: Evaluasi Kinerja Sumber Daya Manusia. Edisi Keenam. (Reflika Aditama, Bandung, 2013)

[3] Wirawan: Evaluasi Kinerja Sumber Daya Manusia. (Erlangga, Jakarta, 2009)

[4] Sidanti, Heny: Pengaruh Lingkungan Kerja, Disiplin Kerja dan Motivasi Kerja Terhadap Kinerja Pegawai Negeri Sipil di Sekretariat DPRD Kabupaten Madiun. Jurnal JIBEKA. Vol 9. No 1. Pp 44-53.(2015)

[5] Anggoro, Rendra. Rizak, Basri. Jam'an, Andi: Kompetensi dan Motivasi Terhadap Kinerja Aparatur Sipil Negara pada Dinas Kebudayaan dan Kepariwisataan. Jurnal STIEAMKOM. Vol.1 No.3. Pp 23-34 (2018).

[6] Efendi,Sugito dan Rw. Alamsyah: Pengaruh Budaya Organisasi, Gaya Kepemimpinan dan Motivasi Terhadap Kinerja Pegawai Negeri Sipil Pemerintah Kabupaten Konawe Selatan Provinsi Sulawesi Tenggara. Jurnal Ilmu dan Budaya. Vol. 5, No. 45. Pp 5323-5350 (2015).

[7] Rivai, Veitzal. Bachtiar. Amar, B.R: Pemimpin dan Kepemimpinan Dalam Organisasi. (PT Raja Gafindo Persada, Jakarta, 2013) 
[8] Wijayanti, Ratna. Miftaudin: Analisa Pengaruh Kepemimpinan Islami,Motivasi, Kepuasan kerja dan Lama Kerja Terhadap Kinerja. Jurnal PPKM. Vol. III, Pp. 185-192 (2016)

[9] Aswadi, M. Suparman, Lalu. Abidin, Zainal. Analisis Pengaruh Kepemimpinan Islami dan Etos Kerja Islami Terhadap Kinerja Islami Pegawai dengan Budaya Organisasi Sebagai Moderating Variabel (Studi pada Rumah Sakit Islam Siti Hajar Mataram). JMM Unram. (2017)

[10] Hasibuan, H Melayu SP.: Manajemen Sumber Daya Manusia, Edisi Revisi. (Bumi Aksara, Jakarta, 2016).

[11] Nugraheni., Khasifah.: Pengaruh Disiplin Kerja, Beban Kerja dan Lingkungan Kerja Terhadap Kinerja. Diponegoro Journal of Management.Vol.5,No.1.Pp.1-7 (2016)

[12] Mahale,Dewi, Y.A. Lucky, O.H.Dotulong. Tawas,Hendra N.: Pengaruh Disiplin Kerja, Penempatan dan Pelatihan Terhadap Kinerja Jurnal EMBA.Vol 5.No2p 706-713. (2017).

[13] Suwuh,Meisy.: Pengaruh Kepemimpinan,Motivasi dan Disiplin Kerja. Jurnal EMBA Vol 3, No 4 Pp. 611-619 (2015)

[14] Dessler, Gary.: Human Resource Management, $13^{\text {Th }}$ Edition, Prentice Hall,2013

[15] Roring, F.: Pengaruh Kepemimpinan, Pembagian Kerja dan Kompensasi Terhadap Kinerja Karyawan pada PT Bank Danamon Cabang Manado. Jurnal JMBI. Vol 4, No.3, Pp.144-154. (2017)

[16] Amirullah.: Pengantar Manajemen. (Mitra Wacana Muda, Jakarta, 2015).

[17] Mahmudi.: Manajemen Sektor Publik. Edisi Kedua. (UPT STIM YKPN, Yogyakarta, 2010)

[18] Sudarmanto.: Kinerja dan Pengembangan Kompetensi Sumber Daya Manusia. (Pustaka Pelajar, Yogyakarta, 2018).

[19] Uno,Hamzah B.: Teori Motivasi dan Pengukurannya. (PT Bumi Aksara, Jakarta, 2011)

[20] Samsudin, Sadili.: Manajemen Sumber Daya manusia. Pustaka Setia. Bandung. 2010

[21] Sunyoto, Danang: Manajemen Sumber Daya Manusia. Cet. 1. (CAPS (Center For Academic Publising Service). Yogyakarta 2012,)

[22] Robbins, S. P. and Timothy A. Judge.: Organizational Behavior. 15th Edition. (Pearson Education, Inc. New Jersey, 2013)

[23] Ahmad, K.: Leadership and Work Motivation from the Cross-cultural Perspective. International Journal of Commerce and Management. Vol. 19 No.1. Pp 72-84 (2009

[24] Akbar, Surya. Analisa Faktor-Faktor yang Mempengaruhi Kinerja Karyawan. JIAGANIS, Vol 3 No. 2, Hal 1-17, (2018)

[25] Widodo, Suparno.: Manajemen Sumber Daya Manusia. (Pustaka Pelajar. Yogyakarta. 2015)

[26] Hakim, Abdul.: The Implementation of Islamic Leadership and Islamic Organizational Culture and Its Influence on Islamic Working Motivation and Islamic Performance PT Bank Mumalat Tbk Employee In The Central Java.Asia Pacific Management Review (17).1. Pp 77-90 (2012).

[27] Sinungan, Muchdarsyah.. Dasar-Dasar Dan Teknik Manajemen. (Bumi Aksara. Jakarta 2011)

[28] Roeleejanto, Catherine. Brasit, Nurdin. Payangan, otto. Pahlevi, Cepi.: Effect of Leadership, Competency, and Work Discipline on The Application of Total Quality Management and Employees' Performance for The Accrediatation Status Achievement of Government Hospitals in Jakarta, Indonesia. Scientific research Jouenal (SCIRJ), Volume III. Issue XI (2015)

[29] Andry: Pengaruh motivasi terhadap disiplin dan kinerja pegawai pada dinas pendapatan daerah pekanbaru. Jurnal Wiraekonomi mikroskil JWEM. Volume 8 No 02 (2018).

[30] Achmad, Akmal Umar, Budiman.: Pengaruh Motivasi Kerja Dan Kompetensi Terhadap Kinerja Pegawai Melalui Disiplin Kerja. Jurnal Mirai Management Volume 3 No.2 (2018)

[31] Damri, Ulfah, dkk.: Pengaruh Komitmen Organisasi, Kepuasan Kerja, dan Kepemimpinan terhadap Disiplin Kerja Pegawai Biro Administrasi Pemerintahan Umum Provinsi Riau Jurnal Online Mahasiswa Fakultas Ekonomi Universitas Riau Vol 4 No. 1 (2017)

[32] Liyas, Jeli Nata. Pengaruh Kepemimpinan Terhadap Disiplin Kerja Karyawan pada PT Bank Syariah Mandiri. Jurnal Ekonomi dan Bisnis Islam. Vol. 2 No.2. (2017).

[33] Susanty, Aries. Baskoro, Sigit Wahyu.: Pengaruh Motivasi Kerja dan Gaya Kepemimpinan Terhadap Disiplin Kerja Serta Dampaknya pada Kinerja Karyawan (studi Kasus pada PT PLN (Persero) Apd Semarang. Jurnal Teknik Industri Universitas Diponegoro Volume 7 No. 2 Pp 77-84 (2013) 
[34] Santoso, Joko.: Pengaruh Kepemimpinan Terhadap Kinerja Pegawai Dengan Disilin Kerja Sebagai Variabel Intervening (pada Kantor Wilayah Kementrian Agama Provinsi Kalimantan Tengah). Master Thesis. Universitas terbuka (2014)

[35] Ghozali, Imam, dan Latan, Hengky.: Partial Least Square Konsep, Teknik dan Aplikasi Menggunakan Program SmartPLS 3.0. (Universitas Diponegoro, Semarang, 2014)

[36] Khanka, SS.: Human Resource Management. First Edition-2003. (S. Chand Company Ltd Reprint,2013) 